\title{
HUBUNGAN PENDAPATAN, TINGKAT PENDIDIKAN DAN TINGKAT KECUKUPAN ENERGI TERHADAP STATUS GIZI IBU HAMIL
}

\author{
Cahya Ningsih ${ }^{1}$, Rifatul Masrikhiyah $^{2 *}$ \\ 1,2 Program Studi Ilmu Gizi, Fakultas Ilmu Kesehatan, Universitas Muhadi Setiabudi, Indonesia \\ *e-mail: ${ }^{2}$ rifatul.masrikhiyah@gmail.com
}

\begin{abstract}
ABSTRAK
Kekurangan Energi Kronik (KEK) merupakan kondisi wanita usia subur (WUS) dan ibu hamil (bumil) menderita kekurangan energy dan protein sehingga menimbulkan gangguan kesehatan. Tujuan penelitian ini adalah untuk mengetahui hubungan pendapatan, tingkat pendidikan dan tingkat kecukupan energi terhadap status gizi ibu hamil di Desa Malahayu Kecamatan Banjarharjo Kabupaten Brebes. Desan Penelitian ini menggunakan crossectional. Responden dalam penelitian ini yaitu ibu yang mengalami kehamilan yang tinggal di Desa Malahayu. Jumlah responden dalam penelitian ini sebanyak 30 responden yang ditentukan menggunakan teknik random sampling. Instrumen yang digunakan dalam penelitian ini berupa kuesioner wawancara (data pendapatan dan tingkat pendidikan) dan kuesioner recall 1x24 jam (tingkat kecukupan energi). Pengujian hipotesis dalam penelitian ini menggunakan uji chi square untuk mengetahui hubungan pendapatan, pendidikan dan asupan energi terhadap status gizi ibu hamil. Hasil penelitian diperoleh bahwa terdapat hubungan antara pendapatan, pendidikan dan asupan energi terhadap status gizi ibu hamil ditunjukkan dengan nilai $\mathrm{p}<0,05$. Kesimpulan dari penelitian ini yaitu terdapat hubungan pendapatan, tingkat pendidikan dan asupan energi terhadap status gizi ibu hamil di Desa Malahayu Kecamatan Banjarharjo Kabupeten Brebes.
\end{abstract}

Kata kunci: Status Gizi, Pendapatan, Asupan Makanan, Pendidikan

\begin{abstract}
Chronic Energy Deficiency (KEK) is a condition of women of childbearing age (WUS) and pregnant women (bumil) suffer from lack of energy and protein that cause health problems. The purpose of this study was to find out the relationship of income, education level and energy adequacy level to the nutritional status of pregnant women in Malahayu Village of Banjarharjo District of Brebes Regency. This study uses crossectional. Respondents in this study were mothers who experienced pregnancy living in Malahayu Village. The number of respondents in this study as many as 30 respondents were determined using random sampling techniques. The instruments used in the study included interview questionnaires (income and education level data) and 1x24-hour recall questionnaires (energy adequacy levels). Hypothesis testing in this study used the chi square test to determine the relationship of income, education and energy intake to the nutritional status of pregnant women. The results of the study found that there is a relationship between income, education and energy intake to the nutritional status of pregnant women indicated by a value of $p<0.05$. The conclusion of this study is that there is a relationship of income, education level and energy intake to the nutritional status of pregnant women in Malahayu Village, Banjarharjo District, Brebes Regency.
\end{abstract}

Keywords: Nutritional Status, Income, Food Intake, Education

\section{PENDAHULUAN}

Status gizi ibu hamil merupakan keadaan dimana keseimbangan tubuh ibu hamil sebagai akibat dari pemasukan asupan makanan dan pengeluaran energi yang digunakan dalam malakukan aktivitas tubuh, zat zat gizi yang digunakan untuk kelangsungan hidup serta mempertahankan fungsi fungsi organ tubuh ibu hamil. Kurang energi kronis (KEK) merupakan masalah status gizi ibu hamil yang sering dijumpai dimana keadaan tersebut dapat menghambat perkembangan dan pertumbuhan janin dalam kandungan ibu hamil.[1]. Status gizi ibu hamil yang kurang baik dapat diukur dari kondisi ibu hamil saat kekurangan energi kronis, dimana kondisi tersebut disebabkan kurangnya asupan makanan terutama asupan makanan sumber energi dan 
makanan yang mengandung gizi mikro. Kehamilan merupakan kondisi dimana didalam rahim seorang wanita terdapat embrio atau fetus. Adanya embrio didalam rahim ibu hamil yang menyebabkan kebutuhan energi maupun gizi mikro meningkat terutama pada saat trimester III. Peningkatan kebutuhan energi dan zat gizi mikro menyebabkan asupan makanan yang harus masuk kedalam tubuh ibu hamil meningkat terutama makanan sumber energi. Kekurangan energi dapat mengakibatkan malnutrisi pada ibu hamil atau disebut kekurangan energi kronik. Kondisi kekurangan energi kronik dapat berimbas pada pertumbuhan dan perkembangan anak terhambat dan dapat meningkatkan resiko Berat Bayi Lahir Rendah (BBLR) [2].

Masalah gizi kurang masih menjadi masalah besar dinegara berkembang seperti Indonesia. Jumlah ibu hamil yag mengalami gizi kurang di Indonesia masih cukup tinggi. Hal tersebut disebabkan kurangnya pemenuhan kebutuhan ibu hamil dan janinnya dari asupan makanan selama masa kehamilan [3]. Persentasi atau jumlah keseluruhan kasus KEK pada ibu hamil di Indonesia mencapai 24,2 \% sedangkan di provinsi Jawa Tengah mencapai 23\% (Riskesda, 2013). Berdasarkan data yang diperoleh dari Puskesmas Pembantu (PUSTU) Desa Malahyu jumlah ibu hamil yang memeriksakan diri ke puskesmas sebanyak 79 orang dimana 31 ibu hamil mengalami kekurangan energy kronik (KEK).

Pendapatan seseorang berkaitan dengan penghasilan dimana pendapatan akan memengaruhi pemenuhan kebutuhan asupan makanan keluarga baik dari segi kualitas ataupun kuantitas. Rendahnya pendapatan keluarga akan berimbas pada kurangnya pemenuhan kebutuhan makanannya sehingga akan mempengaruhi status kesehatan keluarga [4]. Kualitas dan kuantitas asupan makanan akan mempengaruhi status kesehatan keluarga, selain itu juga kebergaman makanan yang dikonsumsi maka makin baik mutu makanannya yang dapat memberikan manfaat yang besar terhadap kesehatan ibu hamil [5]. Adanya pantangan dan larangan yang masih dipercaya dinegara berkembang menyebabkan peluang ibu hamil mengkonsumsi makanan yang beragam, sehingga berakibat konsumsi makanan yang bergizi ibu hamil terbatas dan kurang. Hal tersebut menjadi sumber masalah terjadinya penyakit kekurangan gizi pada ibu hamil mudah tumbuh dimasyarakat [6].

Pendidikan merupakan salah satu ukuran yang digunakan dalam status sosial ekonomi. Tingkat pendidikan yang relatif tinggi akan mempengaruhi akses mendapatkan pekerjaan dan pendapatan yang lebih baik. Pendapatan yang tinggi maka jumlah makanan dan jenis makanan yang dimakan atau dipenuhi juga lebih baik [7]. Berdasarkan latar belakang yang sudah diurakan maka peneliti tertarik untuk membahasa atau meneliti menganai hubungan pendapatan, pendididkan dan asupan energi terhadap ststus gizi ibu hamil di Desa Malahayu Kecamatan Banjarharjo Kabupaten Brebes.

\section{BAHAN DAN METODE}

Desain penelitian yang digunakan untuk mengetahui hubungan pendapatan, pendidikan dan asupan energi terhadap status gizi ibu hamil adalah crosssectional. Populasi yang digunakan dalam penelitian ini adalah seluruh ibu hamil di desa Malahayu Kecamatan Banjarharjo Kabuppaten Brebes. Jumlah sempel dalam penelitian ini sebanyak 30 responden ibu hamil menggunakan teknik random sampling. Variabel penelitian ini terdiri dari variabel bebas yaitu pendapatan, pendidikan dan asupan energi sedangkan variabel terikatnya yaitu status gizi ibu hamil dalam hal ini yaitu kurang energi kronik (KEK). Data yang diperoleh didapat melalui kuesioner wawancara dan kuesioner recall 1x24 jam. Data dianalisis menggunakan uji chi-square untuk menguji hipotesis apakah terdapat hubungan antara pendapatan, tingkat pendidikan, tingkat kecukupan energi terhadap status gizi ibu hamil di Desa Malahayu Kecamatan Banjarharjo Kabupaten Brebes.

\section{HASIL DAN PEMBAHASAN}

Responden dalam penelitian ini yaitu 30 responden ibu hamil di desa Malahayu Kecamatan Banjarharjo Kabupaten Brebes. Pengambilan lokasi penelitian ini berdasarkan prevalensi ibu hamil yang tinggi di kecamatan banjarharjo yaitu desa Malahayu. Gambaran karakteristik responden disajikan pada tabel 1 . 
Tabel 1. Gambaran karakteristik responden

\begin{tabular}{lcc}
\hline \multicolumn{1}{c}{ Jenis } & Nilai & \\
\cline { 2 - 3 } & Mean & Min - Maks \\
\hline Umur Responden (tahun) & 26,2 & $19-35$ \\
\hline Umur Kehamilan (minggu) & 22 & $13-43$ \\
\hline
\end{tabular}

Gambaran karakteristik responden yang digunakan dalam penelitian ini dapat dilihat pada Tabel 1 yang meliputi umur responden dan umur kehamilan responden. Rerata umur responden yaitu 26,2 tahun dengan rentang umur responden yang paling muda yaitu 19 tahun dan yang paling tua berumur 35 tahun. Rerata umur kehamilan responden yaitu 22 minggu dengan rentang umur kehamilan responden yang paling muda berumur 13 minggu dan yang umur kehamilannya paling tua berumur 43 minggu.

Tabel 2. Hubungan Pendapatan dengan Status Gizi pada ibu hamil

\begin{tabular}{lccccc}
\hline \multirow{2}{*}{ Pendapatan } & \multicolumn{2}{c}{ Status Gizi } & Total & RR & Nilai P \\
\cline { 2 - 3 } & KEK & Normal & & & \\
\hline Kurang & 15 & 0 & 15 & 2,14 & $0,004^{*}$ \\
\hline Cukup & 7 & 8 & 15 & & \\
\hline Kenn
\end{tabular}

Keterangan *ada hubungan antara pendapatan dengan kurang energi kronik (KEK) nilai $\mathrm{p}<0,005$

Berdasarkan Tabel 2, jumlah responden dengan tingkat pendapatan cukup sebanyak 15 orang, terdiri dari 7 orang KEK dan 8 orang tidak KEK. Responden berpenghasilan kurang sebanyak 15 responden yang seluruhnya menderita KEK. Hasil uji chi-square menunjukkan ada hubungan antara tingkat pendapatan dengan status gizi ibu hamil dilihat dari nilai $\mathrm{p}(0,004)<0,005$. Hubungan kekuatan antara pendapatan dengan KEK pada ibu hamil sebesar 2,14 yang artinya ibu hamil dengan pendapatan kurang memiliki resiko terkena KEK 2,14 kali dari pada ibu hamil dengan pendapatan cukup. Hal tersebut disebabkan pendapatan yang rendahnya akan berimbas pada kurangnya pemenuhan kebutuhan makanannya sehingga akan mempengaruhi status kesehatan keluarga [4]. Penelitian ini sejalan dengan penelitian yang dilakukan oleh Anggraini menyatakan bahwa terdapat hubungan pendapatan dengan kejadian KEK pada ibu hamil di kota Metro Provinsi Lampung [6].

Tebal 3. Hubungan Pendidikan dengan Status Gizi pada Ibu hamil

\begin{tabular}{lccccc}
\hline \multirow{2}{*}{ Pendidikan } & \multicolumn{2}{c}{ Status Gizi } & Total & RR & Nilai P \\
\cline { 2 - 3 } & KEK & Normal & & & \\
\hline Kurang & 16 & 0 & 16 & 2,14 & $0,002^{*}$ \\
\hline Cukup & 6 & 8 & 14 & & \\
\hline
\end{tabular}

Keterangan *ada hubungan antara pendapatan dengan kurang energi kronik (KEK) nilai $p<0,005$

Berdasarkan tabel 3 menunjukkan bahwa jumlah responden yang memiliki pendidikan cukup sebanyak 14 orang responden yang terdiri dari 6 orang responden menderita KEK dan 8 orang responden yang tidak menderita KEK/Normal. Jumlah responden yang memiliki pendidikan kurang sebanyak 16 orang yang terdiri dari 16 orang responden menderita KEK. Hasil Uji Chi-square menunjukkan bahwa terdapat hubungan antara pendidikan dengan KEK pada Ibu hamil dimana nilai $\mathrm{p}<0,005$ yaitu nilai $\mathrm{p}=0,002$. Hubungan kekuatan antara penddidikan dengan KEK pada ibu hamil sebesar 2,14 yang artinya ibu hamil dengan pendidikan kurang memiliki resiko terkena KEK 2,14 kali dari pada ibu hamil dengan pendidikan cukup. Hal ini disebabkan karena kurangnya pengetahuan ibu atau kurang pahamnya ibu mengenai makanan yang memiliki kandungan zat gizi yang baik, seberpa besar porsi yang dibutuhkan untuk memenuhi kebutuhan zat gizi pada ibu hamil, bagaimana cara pengolahan makanan yang baik sehingga zat zat gizi yang terdapat dalam makanan tidak mengalami penurunan yang signifikan setelah dilakukan pengolahan dan kurang beragamnya makanan yang ibu hamil makan karena terdapat pantangan sehingga zat gizi tidak terpenuhi yang mengakibatkan ibu mengalami KEK [8]. Penelitian ini sejalan dengan penelitian yang dilakukan oleh Rahmaniar, yang menunjukkan bahwa 6 dari 32 
ibu hamil berpendidikan rendah menderita KEK dan 15 dari 28 ibu hamil berpendidikan cukup menderita KEK dengan $\mathrm{RR}=0,246$. Hasil analisis statistik menunjukkan bahwa tingkat pengetahuan berhubungan dengan kejadian KEK. Oleh karena itu, semakin banyak informasi seorang ibu, semakin kecil kemungkinan dia untuk menderita KEK [9].

\section{Tebal 4. Hubungan Tingkat Kecukupan Energi dengan Status Gizi pada Ibu hamil}

\begin{tabular}{lccccc}
\hline \multicolumn{1}{c}{ Tingkat } & \multicolumn{2}{c}{ Status Gizi } & Total & RR & Nilai P \\
\cline { 2 - 3 } Kecukupan Energi & KEK & Normal & & & \\
\hline Kurang & 21 & 3 & 24 & 25,0 & $0,003^{*}$ \\
\hline Cukup & 1 & 5 & 6 & & \\
\hline
\end{tabular}

Keterangan *ada hubungan antara pendapatan dengan kurang energi kronik (KEK) nilai $p<0,005$

Berdasarkan tabel 4 menunjukkan bahwa jumlah responden yang memiliki asupan energi cukup sebanyak 6 orang responden yang terdiri dari 1 orang responden menderita KEK dan 5 orang responden yang tidak menderita KEK/Normal. Jumlah responden yang memiliki asupan energi kurang sebanyak 24 orang yang terdiri dari 21 orang responden menderita KEK dan 3 orang responden tidak menderita KEK/Normal. Hasil Uji Chi-square menunjukkan bahwa terdapat hubungan antara tingkat kecukupan energi dengan status gizi pada Ibu hamil dimana nilai $p<0,005$ yaitu nilai $p=0,003$. Hubungan kekuatan antara tingkat kecukupan energi dengan KEK pada ibu hamil sebesar 25 yang artinya ibu hamil dengan asupan energi kurang memiliki risiko terkena KEK 25 kali dari pada ibu hamil dengan asupan energi cukup. Hal tersebut disebabkan oleh pola makan, konsumsi makan dan kebergamana makanan yang dikonsumsi oleh ibu hamil yang kurang baik menyebabkan tidak tercukupinya kebutuhan energi selama hamil [10]. Penelitian ini sejalan dengan penelitian yang dilakukan oleh Rahmaniar (2013) yang menyebutkan bahwa ada hubungan pola makan dengan kejadian KEK pada ibu hamil di Tampa Padang, Kabupaten Mamuju, Sulawesi Barat, diketahui bahwa ada hubungan pola makan dengan kejadian KEK[9]. Penelitian ini sejalan dengan penelitian yang dilakukan asri, 2019 yang dilakukan pada buruh perempuan di desa prapag lor dan prapag kidul kec. Losari kabupaten brebes menunjukkan bahwa terdapat hubungan antara asupan energy dengan status gizi buruh perempuan [11], akan tetapi penelitian ini berseberangan dengan penelitian yang dilakukan di pondok pesantrean Al Asror, Gunungpati, Semarang menunjukkan tidak ada hubungan antara asupan energy dengan persen lemak tubuh [12].

\section{KESIMPULAN}

Responden dalam penelitian ini memiliki umur rata - rata 26,2 tahun dan memiliki usia kandungan rata - rata 22 minggu. Terdapat hubungan antara penghasilan, pendidikan dan asupan energi terhadap status gizi ibu hamil di Desa Malahayu Kecamatan Banjarharjo Kabupaten Brebes.

\section{DAFTAR PUSTAKA}

[1]. Vita, K. M. (2014, April). Faktor-Faktor Yang Berhubungan Dengan Kekurangan Energi Kronis (KEK) Pada Ibu Hamil Di Kecamatan Kamoning Dan Tambelangan, Kabupaten Sampang, Jawa Timur. Retrieved from https://e-journal.unair.ac.id

[2]. Siti, K. P. Hubungan Pendapatan Keluarga Dan Tingkat Pendidikan Ibu Dengan Kejadian Kekurangan Energi Kronis (KEK) Pada Ibu Hamil Di Wilayah Kerja Puskesmas Puuwatu Kota Kendari Provinsi Sulawesi Tenggara, Skripsi, Program Sarjana Terapan Kebidanan, Politeknik Kesehatan Kendari, 2018, Sulawesi Tenggara. Retrieved from http://repository.poltekke

[3]. Kementerian Kesehatan RI. 2015. Pedoman Penanggulangan Kurang Energi Kronik (KEK) Pada Ibu Hamil. Jakarta.

[4]. Fidyah, A., Atika, W., \& Ria, P. L. (2014, Oktober). Pengaruh Kekurangan Energi Kronik (KEK) Dengan Kejadian Anemia Pada Ibu Hamil. Jurnal Kesehatan, Vol. 5 No. 2. Retrieved from https://ejurnal.poltekkes.tjk.ac.id 
[5]. Nurul, U. R., Mustamin, Agustian, I., Siti, N. R. (2018, Mei). Pendapatan Keluarga Dengan Kurang Energi Kronik (KEK) Pada Ibu Hamil. Media Gizi Pangan, Vol. 25 No 2. Retrieved from http://journal.poltekkes

[6]. Anggraini, Y. (2013, Oktober). Pengaruh Demografi Dan Sosioekonomi Pada Kejadian Kekurangan Energi Kronik Ibu Hamil Di Kota Metro Provinsi Lampung. Jurnal Kesehatan, Vol. 4 No. 2. Retrieved from https://ojs.ac.id

[7]. Farida, H. Hubungan Antara Pola Konsumsi, Penyakit Infeksi, Dan Pantang Makanan Terhadap Risiko Kurang Energi Kronik (KEK) Pada Ibu Hamil Di Puskesmas Ciputat Kota Tangerang Selatan, Skripsi, Program Sarjana Kesehatan Masyarakat, Universitas Islam Negeri Syarif Hidayatuallah Jakarta, 2011, Jakarta. Retrieved from https://repository.uinjkt.ac.id

[8]. Rizky, S. R. \& Misra. (2017, Oktober). Faktor-Faktor Yang Berhubungan Dengan Kejadian Kekurangan Energi KroniK (KEK) Pada Ibu Hamil di Wilayah Kerja Puskesmas Krueng Barona Jaya. Journal of Healthcare Technology and Medicine, Vol. 3 No. 2. Retrieved from https://jurnal.uui.ac.id

[9]. Rahmaniar, A. (2013,Februari). Faktor-Faktor Yang Berhubungan Dengan Kekurangan Energi Kronis Pada Ibu Hamil Di Tampa Padang, Kabupaten Mamuju, Sulawesi Barat. Media Gizi Masyarakat Indonesia, Vol. 2 No. 2. Retrieved from http://ojs.ac.id

[10]. Evi, Y. N., Jusuf, E., Dewi, M. D. H., Ponpon, S. I., Endang, S., Johanes, C. M., \& Yoni, F. S. (2014, Desember). Asupan Energi dan Protein Setelah Program Pemberian Makanan Tambahan Pemulihan Ibu Hamil Kurang Energi Kronik di Puskesmas Kota Surabaya. Indonesian Journal Of Education and Midwifery Care (IJEMC), Vol. I No 1. Retrieved from http://ijemc.unpad.ac.id/ijemc

[11]. Koryaningsih A, Wahyani AD. Hubungan Antara Asupan Energi Dan Aktivitas Fisik Dengan Obesitas Pada Buruh Perempuan. Jurnal Ilmiah Gizi dan Kesehatan (JIGK). 2019 Aug 29;1(01):11-8. Retrieved from http://jurnal.umus.ac.id/index.php/JIGK

[12]. Sholichah, F. ., Aqnah, Y. I. ., \& Sari, C. R. . (2021). Asupan Energi Dan Zat Gizi Makro Terhadap Persen Lemak Tubuh. Jurnal Ilmiah Gizi Dan Kesehatan (JIGK), 2(02), 15-22. https://doi.org/10.46772/jigk.v2i02.452.

Retrieved

from http://jurnal.umus.ac.id/index.php/JIGK 